\title{
Preliminary Insights into the Nature of Graduate IS Programmes in Sub-Saharan Africa
}

\author{
Mark-Oliver Kevor, Richard Boateng ${ }^{(\triangle)}(\mathbb{D})$, \\ Emmanuel Awuni Kolog (D), Acheampong Owusu (D), \\ and Anthony Afful-Dadzie \\ University of Ghana Business School, Box LG 78 Accra, Ghana \\ Richboateng@ug.edu.gh
}

\begin{abstract}
Extant Information Systems (IS) curriculum research has focused on the nature of undergraduate IS programmes, particularly in the US and UK, eliciting calls for studies on graduate IS programmes and in regions beyond the US and UK. This study, consequently, looks at the nature of graduate IS programmes in Sub-Saharan Africa (SSA). Using a direct survey method, IS courses information were collected from the websites of top universities in SSA based on a 2019 webometric world ranking of universities. The course offerings from these universities are mapped to the competencies specified in the Global competency model for graduate IS programmes (MSIS 2016). The findings generally indicate, among others, non-adherence of graduate IS programmes in SSA to the MSIS 2016. The reasons for the non-adherence to the MSIS 2016 curriculum model is recommended for future research.
\end{abstract}

Keywords: MSIS 2016 adherence $\cdot$ IS curriculum · Adoption $\cdot$ Sub-Saharan Africa

\section{Introduction}

It is becoming well-accepted that the aim of information systems (IS) curriculum design and delivery is to prepare IS graduates with the skills required by organisations (Benamati et al. 2010; Topi et al. 2017). Recently, organisations have been concerned with the competencies of IS graduates due to the implications - financial and otherwise - of providing on-the-job (i.e. in-service) training to ensure employees can meet the organisations' competency demands (Anderson 2017). Stefanidis et al. (2013, p. 1) claim that 'there is an expectation that IS graduates possess sufficient skills to make their transition into graduate employment as seamless as possible'. As a result, organisations are gradually eliminating trainee positions and preferring to hire graduates with the relevant competencies (Anderson 2017). While this organisational dimension supports expansion and competitiveness, it poses a practical challenge for IS faculty and curriculum developers, who must work to meet the changing demands of businesses in the face of declining IS enrolment (Akbulut-Bailey 2012). 
The IS community has responded to organisations' rapidly changing IS competency needs by developing IS competency models to guide the design and delivery of both graduate and undergraduate programmes in higher education institutions (Gorgone et al. 2006; Topi et al. 2017). While considerable research has examined the level of adoption of IS curriculum models at the undergraduate level (Andoh-Baidoo et al. 2014; Bell et al. 2013; Clark et al. 2017; Lo and Cruz 2014; Mills et al. 2012; Osatuyi and Garza 2014), there is less research on adoption and adherence at the graduate level (Apigian and Gambill 2014; Yang 2012). Moreover, much of the domain-specific research is predominantly conducted in the North American context (Helfert 2011), despite the fact that organisations' IS competency needs differ between regions and regional market factors influence the structure of IS curricula (Larsson and Boateng 2010; Kaiser et al. 2011; Clark et al. 2017). Yang (2012) suggested that researchers should investigate this topic in non-US universities, preferably in other regions of the world. However, in our preliminary investigation, we found no empirical research on the adoption of the IS competency model in Sub-Saharan Africa (SSA). Additionally, according to Yang (2012) and Apigian and Gambill (2014), few studies have been on the adoption of the IS competency model at the graduate level, only with the MSIS 2006 (Gorgone et al. 2006) and none with the global competency model for graduate degree programmes (MSIS 2016) (Topi et al. 2017) which is the latest of the curriculum guidelines developed by a joint committee of professionals specifying competencies required from an IS graduate. Quality graduate IS programmes in SSA presents an opportunity to develop contextual solutions to the myriad of problems challenging the region and other less developed countries (Syler and Venkatesh 2018). In view of these gaps, this paper seeks to understand the nature of graduate IS programmes in SSA and to assess the level of adherence of SSA IS curricula to the MSIS 2016 guidelines. The following research questions are posed: What is the nature of graduate IS programmes in SSA? What courses are offered in graduate IS programmes in SSA to ensure that students attain IS competencies? What is the level of adherence of graduate IS curricula in SSA to the MSIS 2016 guidelines?

The rest of the paper is organised as follows. Section 2 presents the background of the study, including an overview of the MSIS model and IS in higher education. Section 3 describes the research methodology. Section 4 presents the results and discusses them. Section 5 describes the relevant conclusions and suggests a direction for future research.

\section{Background}

\subsection{Information System Programmes in Higher Education Institutions}

Westfall (2012, p. 66) defines IS as a 'field that prepares students to interface between non-technical organizational employees and managers and very technical IT professionals, with a focus on functions that are unlikely to be offshored'. This definition, which we have adopted in the current study, underscores the relevance of understanding the content and curricula of IS programmes in higher education institutions. Research aiming to identify the nature of graduate IS curricula often starts by 
investigating the nomenclature associated with IS programmes in various institutions (Brooks et al. 2016; Cassel et al. 2008; Longenecker et al. 2015). IS programmes can be found within various departments of higher education institutions (Longenecker et al. 2015), and a benchmarking effort in the UK identified more than 6000 different names for computing-related programmes of study and over 150 different names for IS programmes (Cassel et al. 2008). Brooks et al. (2016) found that the terms IS, management information systems (MIS), computer information systems (CIS) and information technology (IT) refer to the same or similar disciplines, indicating that no effort has been put towards developing a naming convention or standard for IS education. Similarly, Pierson et al. (2008) compared the names of IS programmes in 2004 to 2007 to determine whether there was any convergence in the naming of IS programmes in higher education. They found that MIS, IS and CIS are the dominant names, but $20 \%$ of the programmes in the surveyed US schools did not use these names (Pierson et al. 2008). Given the aim of this paper, we believe it is critical to add to the debate on the identity of the IS field (Agarwal and Lucas 2005; Benbasat and Zmud 2003) and investigate the naming conventions of IS programmes in other regions. This will help researchers understand not only the identity of the IS discipline but also distinguish IS from other computing-related disciplines.

\subsection{The MSIS Model in Perspective}

In an attempt to maintain standards and work towards a core body of knowledge in the field of IS, a joint task force created by the Association for Computing Machinery (ACM) and the Association for Information Systems (AIS) developed a model curriculum for IS programmes in various higher education institutions. The most recent model for undergraduate programmes is the IS 2010 (Topi et al. 2010) and for graduate programmes is the MSIS $2016^{1}$ global IS competency model (Topi et al. 2017). The MSIS 2016 model is a revised version of the MSIS 2006 (Gorgone et al. 2006), which was itself a revision of the MSIS 2000 (Gorgone et al. 2000). The MSIS 2000 and MSIS 2006 were developed based on the assumptions and principal characteristics regarding IS in the US and Canada. The MSIS 2016 was the first to consider the context of other regions, such as Asia and Europe. Moreover, whereas its antecedents provide specific recommendations, the MSIS 2016 is a meta-model that specifies necessary competencies and provides guidance for the development of IS curricula or models. This follows the recent emphasis on a competency-based approach to IS curriculum design and delivery (Sutcliffe and Chan 2004; Topi 2016; Topi et al. 2011). According to Sutcliffe and Chan (2004), this approach is more flexible than the coursebased approach, which specifies that certain courses must always be taught.

The MSIS 2016 offers three categories of competencies: IS, individual foundational competencies and core competencies in a domain of practice. These categories cover broad areas of competency as well as specific competencies where appropriate. Nine IS

\footnotetext{
${ }^{1}$ Heikki, T. et al. (2017) "MSIS 2016 Global Competency Model for Graduate Degree Programs in Information Systems," Communications of the Association for Information Systems: Vol. 40, Article 18. Available at: https://aisel.aisnet.org/cgi/viewcontent.cgi? article=3997\&context=cais.
} 
competency areas, 88 specific competencies (omitted in this paper), and 11 indicative foundational competencies are identified. Whilst previous models emphasised competencies in the business domain, MSIS 2016 recognises the applicability of IS beyond business and core competencies in other domains, such as health, law and government.

The MSIS 2016 specifies four levels of competency attainment expected from an IS graduate for each competency: awareness (i.e. the graduate is aware of the existence of the competency), novice (i.e. the graduate has enough knowledge and skills that s/he could perform tasks under supervision while developing the competency further), support (i.e. the graduate has sufficient knowledge and skills to work with others and support those with higher levels of competencies to achieve set goals) and independent (i.e. the graduate can achieve the desired competency outcomes without continuous supervision). A fifth level, expert, cannot be achieved with a graduate-level IS curriculum (Topi et al. 2017). Employees perform IS roles by applying their knowledge, skills and attitudes within organisational structures and processes (Peppard and Ward 2004). The MSIS 2016 prepares graduates to fill these roles by teaching specific competencies beyond the awareness level and provides curriculum profiles for the roles of Business Analyst, Business Information Manager, Enterprise Architect, IT consultant, IT Project Manager and Systems Analyst (CEN 2012).

Extant research has examined the IS curriculum model from various perspectives. One perspective looks at the presence (or absence) of a specific IS competency recommended by the model in a selected number of schools. Andoh-Baidoo et al. (2014) undertook such a study, examined business intelligence and analytics courses in 161 US schools accredited by the Association to Advance Collegiate Schools of Business. They found a considerable difference in the schools offering business intelligence courses and degrees in different departments. Another perspective looks at the IS courses offered by universities to provide students with specific IS competencies or promote certain career tracks. Studies adopting this perspective survey universities with IS programmes, and they can be exploratory in nature, be guided by a model or perform comparisons with existing IS model curricula. In separate studies of graduate IS programmes in the US, Yang (2012) and Apigian and Gambill (2014) compared a list of courses that universities required and deemed valuable with the MSIS 2006 graduate IS curriculum model. This study applies a similar approach, using the MSIS 2016 global IS competency model as the framework.

\section{Methodology}

To study the nature of graduate IS programmes in SSA, we adopted a direct survey approach (Andoh-Baidoo et al. 2014; Apigian and Gambill 2014; Bell et al. 2013; Yang 2012) and thus collected data directly from the websites of the participating institutions. Bell et al. (2013, p. 77) explained that direct surveys are advantageous because they focus on a 'specific program of interest, allowing systematic collection and quantification of data'. The top 50 universities in SSA were selected based on their rankings by Webometrics (2018), which is an initiative of the Cybermetrics Lab, a research group belonging to the Consejo Superior de Investigaciones Científicas, which ranks universities by region in order to improve the web presence of academic and 
research institutions. In this study, the university websites were accessed beginning in September 2018, when the academic calendar for most universities in SSA begin and updated course catalogues are provided. Only English-language websites were selected in this survey. The websites of two universities in the top 50 were in French and were therefore excluded. To fill this gap, we included the 51st and 52nd universities. Since our focus is on graduate programmes, only universities that offered graduate IS programmes were included.

Of the 50 universities included in the survey, 27 either did not offer a graduate IS programme or did not offer information about their graduate IS programme online. Furthermore, the Masters programmes of six universities are exclusively dissertationbased. Since such programmes do not detail the specific competencies a learner will acquire, it would be difficult to include them in this analysis. Five universities provided incomplete information about the offerings of their graduate IS programmes, and three were specialised universities focusing on, for example, health or agriculture. Nine universities offering graduate IS programmes provided complete data that was sufficient for this analysis.

The name of the programme, total number of courses/modules, minimum duration, presence of domain and IS bridge modules, university type, mode of instruction delivery and modules/courses offered within each broad competency category were recorded. These data were obtained from department websites, university yearbooks, rulebooks and programme catalogues. These descriptions were indicative of what broad competencies students were expected to acquire. The courses offered by the universities were mapped to the broad competencies specified in the MSIS 2016. Similar courses were combined into a common category (for example, systems analysis and design and information systems development). 'YES' was used to indicate that at least one course matching a broad competency category was found. For example, 'YES' was used for a university that offers only entrepreneurship courses, as these fit within the IOCE category, even if there are no courses teaching other competencies within the category. A descriptive analysis was performed on the collected data, and the results are presented in Sect. 4.

\section{Results and Discussions}

\subsection{The Nature of Graduate IS Programmes in SSA}

There is generally lack of graduate IS programmes in SSA. This may be as a result of IS being relatively new as compared to other traditional business and computing programmes and may be an indication of the maturity of the IS discipline in SSA. Nevertheless, the nine graduate IS programmes are offered by flagship universities in SSA. Flagship universities are "almost always public, often among the largest in the system or country, and a leading university in a country or an academic system which is looked to for influence and emulation" (Altbach and Balan 2007, p. 8) and relevant in the SSA context (Teferra 2016) to understanding the nature of graduate IS programmes. Again, Larsson and Boateng (2010) argue that different countries have different resources strengths, maturity and approach in offering IS programmes. 
Consequently, of the 50 universities we surveyed, 9 offered a graduate IS programme or an equivalent programme with a different name. This result confirms other studies (Brooks et al. 2016; Pierson et al. 2008) suggesting that there is a lack of standards for the naming of IS programmes and emphasising the multidisciplinary identity of the IS discipline. The institutions and the names of the graduate IS programmes are summarised in Table 1. All are public universities offering different types of degrees, such as MSc, MBA, MCom and MIT, and they are located in six different countries in SSA.

Table 1. Summary of IS graduate programmes in SSA (Source: Authors)

\begin{tabular}{l|l|l|l|l}
\hline University & Type & Country & $\begin{array}{l}\text { Programme } \\
\text { name }\end{array}$ & $\begin{array}{l}\text { Degree } \\
\text { type }\end{array}$ \\
\hline University of Pretoria & Public & $\begin{array}{l}\text { South } \\
\text { Africa }\end{array}$ & $\begin{array}{l}\text { ICT } \\
\text { Management }\end{array}$ & MIT \\
\hline University of Kwazulu Natal & Public & $\begin{array}{l}\text { South } \\
\text { Africa }\end{array}$ & $\begin{array}{l}\text { IS and } \\
\text { Technology }\end{array}$ & Mcom \\
\hline University of Nairobi & Public & Kenya & $\begin{array}{l}\text { IT } \\
\text { Management }\end{array}$ & MSc \\
\hline Makerere University & Public & Uganda & IS & MSc \\
\hline University of Ghana & Public & Ghana & MIS & MBA \\
\hline University of the Free State & Public & $\begin{array}{l}\text { South } \\
\text { Africa }\end{array}$ & CIS & MSc \\
\hline University of Dar Es Salaam & Public & Tanzania & $\begin{array}{l}\text { Health } \\
\text { Informatics }\end{array}$ & MSc \\
\hline $\begin{array}{l}\text { Mbarara University of Sci. and } \\
\text { Technology }\end{array}$ & Public & Uganda & IS & MSc \\
\hline University of Botswana & Public & Botswana & BIS & MBA \\
\hline
\end{tabular}

The minimum number of modules offered is 6 , and the maximum number is 20 , with an average of 13 (12.88). This is not unlike the typical MSIS programme in the US, which offers 10 to 12 modules over three semesters (Topi et al. 2017). Three of the 9 graduate IS programmes offer bridge modules covering both IS and domain-specific competencies. Such modules are important to help learners from diverse backgrounds transition into the programme (Topi et al. 2017). However, this study did not consider the entry requirements for the programmes, and it is therefore difficult to interpret the absence of bridge modules as injurious. A summary of the number of modules and the presence or absence of bridge modules is presented in Table 2.

From Table 2, the minimum duration of a graduate IS programme is 1.5 years, and the average is 2 years for face-to-face (f2f) delivery (regular stream). In line with the recommendations for IS programmes to move beyond business domain (Gorgone et al. 2006; Topi et al. 2017), there is evidence that graduate IS programmes consider the education, geographic information systems (GIS) and health domains, although the business domain remains dominant. 
Table 2. Summary of graduate IS programmes' characteristics in SSA (Source: Authors)

\begin{tabular}{l|l|l|l|l|l}
\hline University & $\begin{array}{l}\text { Number } \\
\text { of } \\
\text { modules }\end{array}$ & Duration & Domain & $\begin{array}{l}\text { Bridge } \\
\text { modules }\end{array}$ & $\begin{array}{l}\text { Instruction } \\
\text { mode }\end{array}$ \\
\hline University of Pretoria & 13 & 2 & Business & Present & F2F \\
\hline $\begin{array}{l}\text { University of } \\
\text { Kwazulu Natal }\end{array}$ & 6 & 2 & General & Absent & F2F \\
\hline University of Nairobi & 10 & 2 & Business & Absent & F2F \\
\hline Makerere University & 13 & 2 & Business/GIS & Absent & F2F \\
\hline University of Ghana & 20 & 2 & Business & Present & F2F \\
\hline $\begin{array}{l}\text { University of the Free } \\
\text { State }\end{array}$ & 13 & 2 & Education & Absent & F2F \\
\hline $\begin{array}{l}\text { University of Dar Es } \\
\text { Salaam }\end{array}$ & 14 & 2 & Health & Present & F2F \\
\hline $\begin{array}{l}\text { Mbarara University of } \\
\text { Science and }\end{array}$ & 11 & 2 & Health/GIS & Absent & F2F \\
Technology & 16 & 1.5 & Business & Absent & F2F \\
\hline $\begin{array}{l}\text { University of } \\
\text { Botswana }\end{array}$ & & & & & \\
\hline
\end{tabular}

\subsection{Courses and Adherence of Graduate IS Curricula in SSA to MSIS 2016}

The results show that information systems development (ISD) and related courses are widely offered in graduate IS programmes in SSA. This supports Surendra and Denton's (2009) suggestion that the defining course in an IS programme is systems analysis and design, on which the core body of knowledge in the IS field depends (Baskerville and Myers 2002). The five most common courses providing IS competencies are ISD, IS Research, Strategic IS Management, IS Project Management and IS Security and Auditing. These findings are similar to those of other researchers (Apigian and Gambill 2014; Yang 2012). Yang (2012) identified IS Analysis/Modelling/Design, IT Infrastructure, Project and Change Management and Management of IS as the four courses most commonly offered in IS programmes by universities in the US, and Apigian and Gambill (2014) identified Database, Management of IS, System Analysis and Design, and Project Management as the most common courses.

We compared the courses offered in graduate IS programmes with the MSIS 2016 global competency model. To do so, we mapped the IS courses offered by the universities to the appropriate broad IS competency categories in MSIS 2016 (which are discussed in Sect. 3). The results are summarised in Table 3. The results show that courses providing competencies within the Data, Information and Content Management (DICM) and Systems Development and Deployment (SDAD) categories have a strong presence in graduate IS curricula in SSA. Fewer courses that cover competencies within the Ethics, Impacts, and Sustainability (ETIS) and the Enterprise Architecture (EARC) categories are provided. Moreover, little attention has been given to the 
categories Innovation, Organisational Change and Entrepreneurship (IOCE), Business Continuity and Information Assurance (BCIA) and IS Strategy and Governance (ISSG).

None of the graduate IS curricula completely followed the MSIS 2016 model. The most adherent curriculum differed by four broad competencies, and the least adherent differed by six. Four of the universities offer courses providing graduate IS competencies in five broad categories, three offer courses that provide competencies in four broad categories and the remaining two offer courses providing competencies in three broad categories. These results are not much different from those of Yang (2012) and Apigian and Gambill (2014) or from studies examining undergraduate programmes (Bell et al. 2013; Clark et al. 2017; Mills et al. 2012). Apigian and Gambill (2014) found that graduate IS programmes in US universities generally exhibited nonadherence to the MSIS 2006, and Yang (2012) found that course offerings differed from the MSIS 2006 in terms of one category. In a survey of undergraduate IS programmes in the US, Bell et al. (2013) found a wide range of non-adherence to the IS 2010 model. Moreover, a number of non-IS courses were required despite their absence in the IS 2010. Similarly, Stefanidis et al. (2012) found generally low adherence to the IS 2010 in a study of undergraduate IS programmes in the UK.

Table 3. Mapping of graduate IS curricula offered by universities in SSA to the broad IS competency categories in MSIS 2016 (Source: Authors)

\begin{tabular}{l|l|l|l|l|l|l|l|l|l|l}
\hline \multirow{2}{*}{ University } & \multicolumn{2}{l|}{ Core IS competencies (MSIS 2016) } \\
\cline { 2 - 5 } & IOCE & ETIS & EARC & BCIA & DICM & ISMO & ISSG & INFS & SDAD & Total \\
\hline $\begin{array}{l}\text { University of } \\
\text { Pretoria }\end{array}$ & NO & NO & NO & NO & YES & YES & YES & YES & YES & $\mathbf{5}$ \\
\hline $\begin{array}{l}\text { University of } \\
\text { Kwazulu Natal }\end{array}$ & NO & NO & NO & NO & YES & YES & NO & YES & YES & $\mathbf{4}$ \\
\hline $\begin{array}{l}\text { University of } \\
\text { Nairobi }\end{array}$ & YES & NO & NO & YES & NO & YES & YES & YES & NO & $\mathbf{5}$ \\
\hline $\begin{array}{l}\text { Makerere } \\
\text { University }\end{array}$ & NO & NO & NO & YES & YES & NO & YES & YES & YES & $\mathbf{5}$ \\
$\begin{array}{l}\text { University of } \\
\text { Ghana }\end{array}$ & YES & YES & NO & NO & YES & YES & NO & NO & YES & $\mathbf{5}$ \\
\hline $\begin{array}{l}\text { University of the } \\
\text { Free State }\end{array}$ & NO & NO & NO & NO & YES & NO & NO & YES & YES & $\mathbf{3}$ \\
\hline $\begin{array}{l}\text { University of Dar } \\
\text { Es Salaam }\end{array}$ & YES & NO & NO & NO & YES & NO & NO & YES & YES & $\mathbf{4}$ \\
\hline $\begin{array}{l}\text { Mbarara Univ. of } \\
\text { Sci. and Techn. }\end{array}$ & NO & NO & NO & YES & YES & NO & NO & NO & YES & $\mathbf{3}$ \\
\hline $\begin{array}{l}\text { University of } \\
\text { Botswana }\end{array}$ & NO & NO & YES & YES & NO & YES & YES & NO & NO & $\mathbf{4}$ \\
\hline \begin{tabular}{l} 
Total (YES) \\
\hline
\end{tabular} & $\mathbf{3}$ & $\mathbf{1}$ & $\mathbf{1}$ & $\mathbf{4}$ & $\mathbf{7}$ & $\mathbf{5}$ & $\mathbf{4}$ & $\mathbf{6}$ & $\mathbf{7}$ & \\
\hline
\end{tabular}


The current study shows that IS graduates from SSA universities may not have the global IS skills specified in the MSIS 2016 and may require interventions to fill the gaps in their skills, which are associated with extra training costs and time to integrate into organisations, making these graduates less likely to be hired. This continues to be a subject of research, and relevant questions have been raised about the usefulness of the IS curriculum model due to the general non-adherence of universities and whether nonadherence can be further explored.

The results shown in Table 4 also reveal that IS curricula are beginning to move beyond the business and organisational domains, although these domains remain dominant. Previous studies on graduate IS curricula did not analyse domain competencies separately, but this study identified course offerings in non-business domains, such as health, GIS and education. No courses offered competencies in the law or government domains, as suggested by the MSIS 2016. One programme focused only on the core IS competencies, which we refer to as the general (GEN) domain.

No modules or courses provided individual foundational competencies, and it was not clear whether these competencies were embedded in other courses based on the course catalogues. Individual foundational competency modules were identified in a survey of undergraduate IS programmes in the UK (Stefanidis et al. 2012), but not they have not received much attention at the graduate level. A number of studies have advocated for the inclusion of courses in IS curricula that provide individual foundational competencies, including creativity and problem-solving (Martz et al. 2017), service learning (Jones and Ceccucci 2018), virtual teamwork (Chen et al. 2008), intercultural communication (Mitchell and Benyon 2018) and ethics and social responsibility (Harris and Lang 2011).

Table 4. Summary of domain competencies offered by IS graduate programmes in SSA (Source: Authors)

\begin{tabular}{l|l|l|l|l|l|l|l}
\hline University & BUS & HEALTH & LAW & GOVT & GIS & EDU & GEN \\
\hline University of Pretoria & YES & NO & NO & NO & NO & NO & NO \\
\hline University of Kwazulu Natal & NO & NO & NO & NO & NO & NO & YES \\
\hline University of Nairobi & YES & NO & NO & NO & NO & NO & NO \\
\hline Makerere University & YES & NO & NO & NO & YES & NO & NO \\
\hline University of Ghana & YES & NO & NO & NO & NO & NO & NO \\
\hline University of the Free State & NO & NO & NO & NO & NO & YES & NO \\
\hline University of Dar Es Salaam & NO & YES & NO & NO & NO & NO & NO \\
\hline Mbarara Univ. of Science and Techn. & NO & YES & NO & NO & YES & NO & NO \\
\hline University of Botswana & YES & NO & NO & NO & NO & NO & NO \\
\hline Total (YES) & $\mathbf{5}$ & $\mathbf{2}$ & $\mathbf{0}$ & $\mathbf{0}$ & $\mathbf{2}$ & $\mathbf{1}$ & $\mathbf{1}$ \\
\hline
\end{tabular}




\section{Conclusion and Future Studies}

This research sought to identify the nature of graduate IS programmes in SSA and their adherence to the MSIS 2016. Notwithstanding a number of limitations of the study, the findings indicate that traditional business and computer science programmes dominate, although a few universities offer a two-year graduate IS programmes in SSA. The graduate IS programmes generally offer courses providing competencies in SDAD as well as DICM. Courses providing competencies in ETIS and EARC are rare in graduate IS curricula in SSA. Popular core IS courses include ISD, IS Research, Strategic IS Management, IS Project Management and IS Security and Auditing. Whilst this study did not consider specialised courses that provide competencies specific to certain career tracks, we found that the programmes included new domains beyond business. However, there were no specific courses providing individual foundation competencies. We observed different levels of adherence of graduate IS programmes to MSIS 2016. Due to the general non-adherence, many graduates of IS programmes in SSA may not have sufficient skills for the workplace. The reasons for non-adherence were not studied in this research and may be explored in future studies.

A descriptive survey like this, though valuable, does not provide rich insights into how faculties develop or revise graduate IS curricula. Future research could look at specific case studies of graduate IS curricula similar to those of Gupta et al. (2015), and Ramesh and Gerth (2015). Such a study would provide richer insight into the factors that enable or inhibit IS curriculum model adherence than provided by extant literature. These insights could help guide universities in planning graduate IS programmes in SSA. In addition, future research should use all specified competencies during mapping to provide a detailed view of which competencies are provided by courses in graduate IS programmes, moving beyond the broad competencies. Finally, although we compared graduate IS curricula to the competencies specified in MSIS 2016, it is important to understand whether those competencies are exhaustive and relevant to organisations in Africa, as this would guide its adoption or adaptation by universities (Larsson and Boateng 2010). A future study could consider the views of employers, employees and other stakeholders regarding the value of the competencies specified in MSIS 2016 in SSA.

\section{References}

Agarwal, R., Lucas, H.C.: The information systems identity crisis: focusing on high-visibility and high-impact research. MIS Q. 29(3), 381-398 (2005)

Akbulut-Bailey, A.: Improving IS enrolment choices: the role of social support. J. Inf. Syst. Educ. 23(3), 259-271 (2012)

Altbach, P.G., Balan, J. (eds.): Transforming Research Universities in Asia and Latin America: World Class Worldwide. The Johns Hopkins Press, Baltimore (2007)

Anderson, D.L.: Improving information technology curriculum learning outcomes. Informing Sci. 20, 119-131 (2017) 
Andoh-Baidoo, F.K., Villa, A., Aguirre, Y., Kasper, G.M.: Business intelligence \& analytics education: an exploratory study of business \& non-business school IS program offerings. In: Proceedings of the 20th Americas Conference on Information Systems, Savannah, pp. 1-9 (2014)

Apigian, C.H., Gambill, S.: A descriptive study of graduate information systems curriculums. Rev. Bus. Inf. Syst. (Online) 18(2), 47-52 (2014)

Baskerville, R.L., Myers, M.D.: Is information systems a reference discipline? MIS Q. 26(1), 114 (2002)

Bell, C., Mills, R., Fadel, K.: An analysis of undergraduate information systems curricula: adoption of the IS 2010 curriculum guidelines. Commun. Assoc. Inf. Syst. 32(1), 72-95 (2013)

Benamati, J.H., Ozdemir, Z.D., Smith, H.J.: Aligning undergraduate IS curricula with industry needs. Commun. ACM 53(3), 152-156 (2010)

Benbasat, I., Zmud, R.W.: The identity crisis within the IS discipline. MIS Q. 27(2), 183-194 (2003)

Brooks, S., Gambill, S., Clark, J., Clark, C.: What's in a name? An examination of information system degree programs in AACSB international accredited schools. J. High. Educ. Theory Pract. 16(6), 66-76 (2016)

Cassel, L.N., Davies, G., LeBlanc, R., Snyder, L., Topi, H.: Using a computing ontology as a foundation for curriculum development. In: Proceedings of the Sixth International Workshop on Ontologies and Semantic Web for E-learning, pp. 21-29 (2008)

CEN: European ICT professional profiles (ver. 3), Brussels, Belgium (2012). http://www. ecompetences.eu/wp-content/uploads/2014/02/European-e-Competence-Framework-3.0_

CEN_CWA_16234-1_2014.pdf

Chen, F., Sager, J., Corbitt, G., Gardiner, S.C.: Incorporating virtual teamwork training into MIS curricula. J. Inf. Syst. Educ. 19(1), 29-41 (2008)

Clark, J., Clark, C., Gambill, S., Brooks, S.: IS curriculum models, course offerings, and other academic myths/hopes. J. High. Educ. Theory Pract. 17(9), 61-68 (2017)

Gorgone, J.T., Gray, P., Stohr, E.A., Valacich, J.S., Wigand, R.T.: MSIS 2006: model curriculum and guidelines for graduate degree programs in information systems. Commun. Assoc. Inf. Syst. 38(2), 121-196 (2006)

Gorgone, J., et al.: MSIS 2000: model curriculum and guidelines for graduate degree programs in information systems. Commun. Assoc. Inf. Syst. 3(1), 1-63 (2000)

Gupta, B., Goul, M., Dinter, B.: Business intelligence and big data in higher education: status of a multi-year model curriculum development effort for business school undergraduates, MS graduates, and MBAs. Commun. Assoc. Inf. Syst. 36, 449-476 (2015)

Harris, A., Lang, M.: Incorporating ethics and social responsibility in IS education. J. Inf. Syst. Educ. 22(3), 183-190 (2011)

Helfert, M.: Characteristics of information systems and business informatics study programs. Inform. Educ. 10(1), 13-36 (2011)

Jones, K., Ceccucci, W.: International service learning in is programs: the next phase - an implementation experience. IS Educ. J. 16(4), 53-62 (2018)

Kaiser, K.M., Goles, T., Hawk, S., Simon, J.C., Frampton, K.: Information systems skills differences between high-wage and low-wage regions: implications for global sourcing. Commun. Assoc. Inf. Syst. 29(32), 605-626 (2011)

Larsson, U., Boateng, R.: Towards a curriculum adaptation model for IS undergraduate education in Sub-Saharan Africa. In: Molka-Danielsen, J. (ed.) Selected Papers of the 32nd IRIS Seminar. Tapir Academic Press, Sweden (2010) 
Lo, A., Cruz, A.P.: The implementation of the AIS/ACM IS 2010 curriculum by top US universities: an analysis of catalogs and college websites. In: Proceedings of Twentieth Americas Conference on Information Systems, Savannah, pp. 1-13 (2014)

Longenecker, H.E., Babb, J., Waguespack, L.J., Janicki, T.N., Feinstein, D.: Establishing the basis for a CIS (Computer Information Systems) undergraduate program: on seeking the body of knowledge. Inf. Syst. Educ. J. 8(2), 37-61 (2015)

Martz, B., Hughes, J., Braun, F.: Creativity and problem-solving: closing the skills gap. J. Comput. Inf. Syst. 57(1), 39-48 (2017)

Mills, R.J., Velasquez, N.F., Fadel, K.J., Bell, C.C.: Examining IS curriculum profiles and the IS 2010 model curriculum guidelines in AACSB-accredited schools. J. Inf. Syst. Educ. 23(4), 417-428 (2012)

Mitchell, A., Benyon, R.: Adding intercultural communication to an IS curriculum. J. Inf. Syst. Educ. 29(1), 1-10 (2018)

Osatuyi, B., Garza, M.: IS 2010 curriculum model adoption in the United States. In: Proceedings of 20th Americas Conference on Information Systems, Savannah, pp. 1-11 (2014)

Peppard, J., Ward, J.: Beyond strategic information systems: towards an IS capability. J. Strat. Inf. Syst. 13(2), 167-194 (2004)

Pierson, J.K., Kruck, S.E., Teer, F.: Trends in names of undergraduate computer-related majors in AACSB-accredited schools of business in the USA. J. Comput. Inf. Syst. 49(2), 26-31 (2008)

Ramesh, V., Gerth, A.B.: Design of an integrated information systems master's core curriculum: a case study. Commun. Assoc. Inf. Syst. 36, 301-316 (2015)

Stefanidis, A., Fitzgerald, G., Counsell, S.: A comprehensive survey of IS undergraduate degree courses in the UK. Int. J. Inf. Manag. 32(4), 318-325 (2012)

Stefanidis, A., Fitzgerald, G., Counsell, S.: IS curriculum career tracks: a UK study. Educ. Train. 55(3), 220-233 (2013)

Surendra, N.C., Denton, J.W.: Designing IS curricula for practical relevance: applying baseball's 'moneyball' theory. J. Inf. Syst. Educ. 20(1), 77-85 (2009)

Sutcliffe, N., Chan, S.S.: A competency based MSIS curriculum. J. Inf. Syst. Educ. 16(3), 301311 (2004)

Syler, R.A., Venkatesh, V.: Growing doctoral education in Africa: the story of an online course at ICT University in Cameroon. Commun. Assoc. Inf. Syst. 43(1), 1-21 (2018)

Teferra, D.: African flagship universities: their neglected contributions. High. Educ. 72(1), 79-99 (2016)

Topi, H.: IS education: using competency-based approach as foundation for information systems curricula. ACM Inroads 7(3), 27-28 (2016)

Topi, H., Helfert, M., Ramesh, V., Wigand, R.T., Wright, R.T.: Future of master's level education in information systems. Commun. AIS 2011(28), 437-452 (2011)

Topi, H., et al.: MSIS 2016 global competency model for graduate degree programs in information systems. Commun. Assoc. Inf. Syst. 40(1), 1-117 (2017)

Topi, H., et al.: IS 2010: curriculum guidelines for undergraduate degree programs in information systems. Commun. Assoc. Inf. Syst. 26(1), 359-428 (2010)

Webometrics. https://www.webometrics.info/en/Sub-Saharan. Accessed 11 Mar 2018

Westfall, R.D.: An employment-oriented definition of the information systems field: an educator's view. J. Inf. Syst. Educ. 23(1), 63-70 (2012)

Yang, S.C.: The master's program in information systems (IS): a survey of core curriculums of U.S. institutions. J. Educ. Bus. 87(4), 206-213 (2012) 